Würzburg he started his work on protoplasmic continuity, demonstrating its occurrence in the pulvini of Mimosa pudica. He was also able to prove the existence of connexions between the cells of the leaf of Dionea, between the parenchyma cells of the stamens of Berberis, and in many endosperm cells and in ordinary vegetable tissue. These results were given in several communications to the Royal Society, the Cambridge Philosophical Society, and the Quarterly Journal of Microscopical Science 1882 and 1883, and in the Arb. a.d. Bot. Institut Würzburg, Bd. III, in 1884. His best-known paper, with figures showing the connecting threads, is that in the Philosophical Transactions of the Royal Society, Part 3, 1883, pp. 817-63, with three plates. His earliest paper was on the development of the water glands in the leaf of Saxifraga crustata, illustrated by his own drawings (Quart. J. Micro. Sci., 21, 417; 1881). Vegetable tannins, the constitution of the cell wall and middle lamella, and the mucilagesecreting cells of Blechnum and Osmunda (with Tokutaro Ito) (Ann. Bot., 1, 1 ; 1887) were among the other subjects on which he published important papers. Protosplasmic continuity, however, was his dominant research, and he was indefatigable in attempting to perfect his methods and to demonstrate the existence of the fine protoplasmic connexions across the pit-closing membrane of all vegetable cells. Nothing but the best would satisfy him, and weeks might be spent-as the writer well remembersbefore a result which he would pass could be obtained.

I was singularly fortunate in being asked by him in 1898 to work in his own laboratory, and here several happy years were spent with him in perfecting methods and demonstrating continuity between the cells of every plant subjected to investigation. Much of this work has never been published, but our joint papers on "The Histology of the Endosperm of Tamus during Germination" (Proc. Camb. Philos. Soc., 11, Pt. 6; 1902) and on the connecting threads in Pinus sylvestris and other allied species (Phil. Trans. Roy. Soc., 194; 1901) embody important aspects of his work.

Walter Gardiner was a remarkable lecturer and spared no pains fully to illustrate his lectures in an unusual and arresting manner. His afternoon lecture on "The Plant in the War of Nature" at the Royal Institution in 1888, and his evening lecture at the British Association meeting at Newcastle, 1889, on "Plants in the Struggle for Existence", were specially memorable.

Gardiner was awarded the Rolleston Prize by the University of Oxford in 1888, he and William Bateson being declared equal. In 1898 he received the Royal Medal from the Royal Society and in 1905 the degree of Sc.D. was conferred upon him by the University of Cambridge.

A keen naturalist, with a highly developed artistic sense, Gardiner had a very extensive knowledge of his subject, which was enhanced by his frequent visits to Kew, where he did much of his early work in the Jodrell Laboratory. Histological research in Great Britain suffered a great loss when he was incapacitated by illness from continuing his studies.
He married Miss I. W. Campbell, a great-niece of Sir Joseph Hooker, in 1893, to whom, and to their son, Mr. Alan Gardiner, F.L.S., and their daughter, we extend our sympathy. Arthur W. Hill.

\section{Prof. Otfrid Foerster}

Prof: Otfrid Fonrster, one of the most prominent neurologists of the day, whose recent death has been announced, was born in Breslau on November 9, 1873. After receiving his medical education at Breslau, Kiel and Freiburg, he qualified in 1897. He studied under Prof. Dejerine at La Salpétrière, and then became assistant to Prof. Wernicke in the psychiatric clinic at Breslau, where he was appointed professor of neurology and psychiatry in 1921.

Foerster is perhaps best known for the operation to which his name is attached for the treatment of spastic paralysis and tabes, but his most important work consisted in his studies of the motor cortex and peripheral nerves. His principal publications were on the physiology and pathology of co-ordination (1902), co-ordinated movements in health and nervous and mental disease (1903), the essence of choreic motor disturbances (1904), contractures in pyramidal lesions (1906), diseases of the central and peripheral nerves (1923), hyper-ventilation in epilepsy (1925), and the paths of conduction of pain in flaccid and spastic paralysis (1927). He was, formerly, coeditor with Prof. O. Bumke of the "Handbuch der Neurologie" and on the editorial board of the Deutsche Zeitschrift für Nervenheilkunde.

Foerster was a good European and therefore no friend of the Nazis, which may account for his name not appearing in Wer Ist's, the German Who's Who? A eulogy of him, however, appears in the Deutsche Zeitschrift für Neurologie of 1933, on the occasion of his sixtieth birthday, by Prof. Max Nonne of Hamburg. He was well known in Great Britain, where, in 1927, he was elected an honorary member of the Section of Neurology of the Royal Society of Medicine, before which he delivered the ninth Hughlings Jackson Lecture in 1935, published in Brain, 59, 135 (1936), his subject being "The Motor Cortex in Man, in the Light of Hughlings Jackson's Doctrines". $\mathrm{He}$ was elected an honorary fellow of the Society in 1933 . J. D. Rolleiston.

WE regret to announce the following deaths:

Baron Mataro Nagayo, formerly president of the Tokio Imperial University, director of the Japanese Foundation for Cancer Research, and editor of Gann, the Japanese journal of cancer research, on August 16, aged sixty-three years.

Prof. Rudolf Schoenheimer, associate professor of biochemistry in Columbia University, formerly head of the Department of Pathological Chemistry in the University of Freiburg, known for his work on the application of isotopes for the study of intermediary metabolism, on September 11, aged forty-three.

Mr. M. M. Ussishkin, president of the Jewish National Fund and chairman of the Zionist General Council, one of the founders of the Hebrew University, Jerusalem, on October 2, aged seventy-eight. 